\title{
SOCIAL ANXIETY, SOCIAL ACCEPTANCE AND ACADEMIC SELF-PERCEPTIONS IN HIGH-SCHOOL STUDENTS
}

Melita PUKLEK LEVPUŠČEK

Faculty of Arts, Liubliana

Jelka BERCE

Secondary School for Pharmacy, Cosmetics and Health Care, Liubljana

UDK: $316.613 .4-053.6(497.4)$

316.62-053.6(497.6)

Izvorni znanstveni rad

Primljeno: 16. 5. 2011.

The study focused on how social anxiety relates to acceptance among classmates, academic self-efficacy and academic performance in Slovene high-school students. N = 277 students $(58 \%$ females, age 16 to 17) filled in the Social Anxiety Scale for Adolescents, the Sociometric Test, the "Guess Who" technique, and the Academic Self-Efficacy Scale. The students also answered additional questions about their well-being and social acceptance in the classroom. The results revealed that the most socially anxious students belonged to the sociometric group of rejected students, being described by their classmates as anxious and having a negative mood. More socially anxious students reported a lower degree of well-being in the classroom and a lower degree of acceptance by their classmates. Finally, higher social anxiety was related to lower academic self-efficacy but higher academic performance.

Keywords: social anxiety, social acceptance, academic self-efficacy, high-school students

$\triangle$ Melita Puklek Levpušček, University of Ljubljana,

Faculty of Arts, Department of Psychology, Aškerčeva 2, 1000 Ljubliana, Slovenia.

E-mail: melita.puklek@ff.uni-li.si

Adolescence is an important life period when young individuals start to widen their social network, make confidential and intimate friendships and become engaged in romantic relationships (La Greca \& Moore Harrison, 2005). Previous stu- 
DRUŠ. ISTRAŽ. ZAGREB GOD. 21 (2012)

BR. 2 (11 16)

STR. $405-419$

PUKLEK LEVPUŠČEK, $M$. BERCE, J.:

SOCIAL ANXIETY.. dies indicated that adolescent's difficulties in relationship with peers relate to many psychological problems, like depression, social anxiety, loneliness and social withdrawal (e.g., Hecht et al., 1998; Inderbitzen et al., 1997; La Greca \& Lopez, 1998; La Greca \& Moore Harrison, 2005; Vernberg, 1990; Vernberg et al., 1992).

\section{SOCIAL ANXIETY AND SOCIAL ACCEPTANCE}

Social anxiety is characterised by feelings of apprehension, emotional distress and reticent or avoiding behaviour in real or imagined social interactions (Cheek \& Melchior, 1990; Leitenberg, 1990). Previous studies consistently showed its negative relationship with adolescent's social acceptance and self-perceived social competence (Asher \& Wheeler, 1985; Hymel \& Franke, 1985; LaGreca, 1989; La Greca et al., 1988; Puklek \& Vidmar, 2000). It has been theorised that the relationship between social anxiety and peer rejection is reciprocal (Inderbitzen et al., 1997). Socially anxious and inhibited students trigger negative peer reactions because of reticent behaviours and possible lack of social skills. On the other hand, negative experience in a peer group (e.g., lack of classmates who like them and spend time with them, social isolation) leads to doubts in one's social skills, anxious feelings, worries about criticism and humiliation in social interactions and social withdrawal.

In their self-presentation model, Schlenker and Leary (1982) defined social anxiety as the result of one's perception of negative social self-presentation. Individuals who anticipate negative social reactions are prone to experience higher social anxiety. Previous studies in a clinical setting showed that socially anxious adolescents overestimated the severity and probability of negative social events compared to their non-anxious peers (e.g., Rheingold et al., 2003). Inaccurate interpretation of social events as a threat to one's well-being (i.e. cognitive distortions) thus creates a cyclical pattern that maintains fear and avoidance (Clark \& Wells, 1995). Social anxiety may also be triggered by two opposite motivational tendencies (Schlenker \& Leary, 1982): (a) a tendency to leave a good impression in the social environment, and (b) a tendency to doubt in one's ability to be socially successful.

Another important determinant of doubts into one's ability to self-present successfully is the individual's perception of audience as important, influential and critical (Puklek, 1997). Adolescence is a time when vulnerability to social anxiety increases as this developmental period is marked by self-presentational concerns and perceptions of peers as an important but critical reference group. The focus of adolescent's concerns thus become worries about negative social evaluations, 
DRUŠ. ISTRAŽ. ZAGREB GOD. 21 (2012), BR. 2 (116)

STR. $405-419$

PUKLEK LEVPUŠČEK, M., BERCE, J.:

SOCIAL ANXIETY... failures and possible rejections in the peer group or school context (Westenberg et al., 2004). In their social self-presentation, adolescents try to present themselves to the "peer audience" as socially competent, intelligent and assertive; they want to satisfy their need for belonging and self-promotion being constantly aware of social reactions thereof (Puklek Levpušček, 2006). Given the fact that socially anxious youth mostly feel uncomfortable in peer interactions, it is likely that social anxiety interferes with the development and maintenance of positive peer relations (Inderbitzen et al., 1997). Indeed, feelings of social anxiety may impede the quality of adolescent's interactions with peers and relate negatively to the establishment of close friendships (La Greca \& Lopez, 1998). Furthermore, socially anxious adolescents perceived themselves as less accepted by their classmates and less attractive to romantic partners (Glickman \& La Greca, 2004; La Greca \& Lopez, 1998; Strauss et al., 1987). Peers nominate socially anxious mates less frequently as partners whom they like to socialize with and socially anxious adolescents are classified as rejected or neglected in the sociometric test (e.g., Inderbitzen et al., 1997; La Greca \& Lopez, 1998; La Greca \& Stone, 1993). Crick and Ladd (1993), on the other hand, confirmed a positive relationship only between social anxiety and rejected status. According to the authors' explanation, neglected students, as compared to rejected ones, receive at least one positive nomination. They might be quite satisfied with their social status and they do not seek for more friends in the classroom. In contrast, rejected students perceived a higher degree of loneliness and higher degree of multiple indicators of social distress (loneliness, social anxiety and social withdrawal) than students in other sociometric groups (Crick \& Ladd, 1993).

\section{SOCIAL ANXIETY AND ACADEMIC SELF-PERCEPTIONS AND PERFORMANCE}

Feelings of social anxiety in a school setting may not be experienced only in classroom interactions but also in situations of knowledge assessment and grading (especially in oral examination) or exposure in front of the class (e.g., presenting a seminar work, discussing a topic, going up to the blackboard). In such situations, socially anxious students direct their thoughts to social self-image, they are preoccupied with own deficiencies and worried about possible failure (Puklek Levpušček, 2006). Berce (2010) found that socially anxious students were inclined to avoid showing their learning incompetence to other students or a teacher while Delgado Domenech (2010) confirmed that socially more anxious students had a poorer academic self-concept (general academic, verbal, and math self-concept). Regarding academic achievement, previous studies 
showed that students who experience more social anxiety do not necessarily get lower grades than their socially less anxious counterparts (La Greca \& Lopez, 1998; Puklek Levpušček \& Videc, 2008).

\section{AIMS AND HYPOTHESES}

The central aim of the current study was to expand the knowledge on relationship between social anxiety and social acceptance in high-school students. We focused on the relationship (a) between social anxiety and peer perceptions of one's social acceptance in the classroom, and the relationship (b) between social anxiety and self-perceptions of social acceptance and well-being in the classroom. Furthermore, we wanted to find out how social anxiety relates to academic self-efficacy and academic performance.

Based on previous results on the relationship between social anxiety and adolescent's social acceptance (e.g., Crick \& Ladd, 1993; La Greca \& Lopez, 1998; La Greca \& Stone, 1993), we hypothesised that the most socially anxious students will belong to a rejected group of students. Furthermore, more socially anxious students will receive more negative peer nominations in personal and behavioural domains than their socially less anxious classmates. According to previous studies on self-perceived social competence, cognitive distortions and self-perceived social status of socially anxious adolescents (e.g., Glickman \& La Greca, 2004; La Greca \& Lopez, 1998; Puklek \& Vidmar, 2000; Rheingold et al., 2003; Strauss et al., 1987), we hypothesised that socially more anxious high-school students will report lower well-being in the classroom and lower social acceptance by their classmates. Accordingly, they will expect less positive peer nominations and more negative peer nominations than their socially less anxious classmates.

Based on previous results on the relationship between social anxiety and academic self-perceptions and performance (e.g., Berce, 2010; Delgado Domenech, 2010; Puklek Levpušček \& Videc, 2008), we hypothesised that socially more anxious students will report lower academic self-efficacy, but no predictions were made about the relationship between social anxiety and academic achievement.

\section{METHOD}

\section{Participants}

There were 277 adolescents who participated in the study. Of these, 161 were females $(58.1 \%)$ and 116 were males. The participants were students in years 2 and 3 at the upper-secondary education level called "gymnasium". There were 12 classrooms and 20-25 students in each classroom included in the study. Students' mean age was 17.2 years $(\mathrm{SD}=0.63)$. 


\section{Measures}

\section{Social anxiety}

The Social Anxiety Scale for Adolescents (SASA, Puklek \& Vidmar, 2000; Puklek Levpušček, 2008) is a self-report questionnaire for adolescents aged from 12 to 18 years. It measures worries, fears and avoidant behaviour in various social situations (in peer interaction, at school, on stage). The responses are rated on a Likert-type scale $(1=$ not at all true about me, $5=$ completely true). Exploratory factor analysis with 36 items (Puklek \& Vidmar, 2000) yielded two factors: Apprehension and Fear of Negative Evaluation (AFNE) and Tension and Inhibition in Social Contact (TISC); 28 items consistently showed satisfactory factor loadings on one of the two subscales, the result also supported by later validation studies in Slovenia and Spain (Garcia-Lopez et al., 2011; Puklek Levpušček, 2008; Puklek Levpušček \& Videc, 2008). AFNE (15 items) describes adolescent's fears, worries and anticipation of possible negative evaluations by peers and audience (e.g., "I fear of failures that could cause peers' teasing", "During my performance I fear of boring the audience"). TISC (13 items) describes social tension/ relaxation, speech or behaviour inhibition and readiness to expose in social interactions (with known, unknown or opposite-sex peers, in a class discussion). Examples of items: "I prefer listening to talking in a group of unfamiliar peers", "I feel vague uneasiness at parties".

The internal consistencies ( $\alpha$ s) of the subscales and overall SASA score across age groups ranged from 0.71 to 0.92 and the test-retest reliability $r s$ over a one-month time span were between 0.66 and 0.84 (Puklek Levpušček, 2008). The alphas in the current study were $\alpha=0.90$ (for the AFNE subscale), $\alpha=0.83$ (for the TISC subscale), and $\alpha=0.91$ (for the SASA-Total).

AFNE and TISC moderately to highly correlated with other social anxiety scales (Puklek Levpušček, 2008; Garcia-Lopez et al., 2011), self-perceived social incompetence (Puklek \& Vidmar, 2000; Puklek Levpušček, 2004), and self-perceived interpersonal difficulties (e.g., lack of assertiveness, difficulties in public speaking and heterosexual relationships, Puklek Levpušček, 2008). Low to moderate effect sizes were found for the differences between low and high socially anxious student groups in experiencing distractive factors during oral examination (Puklek Levpušček \& Videc, 2008). Additionally, low to moderate positive correlations of the two subscales and SASA-Total with adolescents' neuroticism and negative links with extraversion were established (Puklek Levpušček, 2008).

\section{Social acceptance}

The sociometric test, which was first introduced by Moreno (1934/1953), gives an insight into social relationships among classmates. More specifically, it enables us to identify social ac- 
DRUŠ. ISTRAŽ. ZAGREB GOD. 21 (2012)

BR. 2 (1 16)

STR. $405-419$

PUKLEK LEVPUŠČEK, M., BERCE, J.:

SOCIAL ANXIETY...
(1) TABLE 1

Criteria for classifying

students into

sociometric groups

(Coie \& Dodge, 1988) ceptance of each student in the classroom by classifying students into social status groups (Terry \& Coie, 1991). The 2-dimensional system (Coie et al., 1982), which was used in our study, includes positive and negative peer nominations (the domain of joint socializing was applied in the present study). The two questions that the students answered were: "Whom do you like to socialize with most in this class?" and "Whom do you like to socialize with least in this class?". The students wrote down the names of 3 classmates whom they like to socialize with most and the names of 3 classmates whom they like to socialize with least. Students were not forced to give the three negative nominations (they could nominate less than three classmates or even none). In the next stage, we classified students into five sociometric groups (popular, average, controversial, neglected, rejected). The two nominations were totalled and standardised for students within each classroom. The two standardised scores were then combined to calculate an index of social preference (standardised liked score minus standardised disliked score) and an index of social impact (standardised liked score plus standardised disliked score). In turn, the two indexes were used to determine peer social status (the classification criteria are shown in Table 1).

\begin{tabular}{lcc}
\hline Sociometric Group & Social Preference & Social Impact \\
\hline Popular & $>1.0$ & $\mathrm{zp}>0 ; \mathrm{zn}<0$ \\
Rejected & $<-1.0$ & $\mathrm{Zp}<0 ; \mathrm{zn}>0$ \\
Neglected & $\mathrm{zp}<0 ; \mathrm{zn}<0$ & $<-1.0$ \\
Controversial & $\mathrm{Zp}>0 ; \mathrm{zn}>0$ & $>1.0$ \\
Average & $1.0 \geq(\mathrm{zp}-\mathrm{zn}) \geq-1.0$ & $1.0 \geq(\mathrm{zp}+\mathrm{zn}) \geq-1.0$
\end{tabular}

Note. $\mathrm{zp}=$ standardised liked scores, $\mathrm{Zn}=$ standardised disliked scores, $\mathrm{zp}-\mathrm{Zn}=$ social preference, $\mathrm{zp}+\mathrm{zn}=$ social impact.

The reliability analysis of the sociometric test is only possible in small test-retest intervals (up to two months). The results of studies which used small test-retest intervals indicated reliability coefficients among 0.60 and 0.90 (cf. Pečjak \& Košir, 2002).

Peer nomination technique Guess Who (originally introduced by Hartshorne \& May, 1928) measures peer perceptions of personal characteristics and behaviours of classmates. The students nominate up to three classmates (may include self-nomination) which they consider to fit the specific personal or behavioural description (e.g., Some students look shy and worried. Who in your classroom is like this?). In the study, we used five positive and five negative personal and behavioural domains: Verbal Aggressiveness (VA), Negative Mood (NM), Physical Aggressiveness (PA), Hyperactivity (HI), Anxiety (AN), Pro- 
DRUŠ. ISTRAŽ. ZAGREB GOD. 21 (2012), BR. 2 (116)

STR. $405-419$

PUKLEK LEVPUŠČEK, M., BERCE, J:

SOCIAL ANXIETY... social Behavior (PB), Academic Achievement Orientation (AAO), Relationships with Teachers (RT), Oppositional Behaviour (OB) and Positive Mood (PM). For each student in the classroom we calculated the sum of his/her positive and negative nominations.

Students also answered additional questions about their well-being and self-perceived social acceptance in the classroom: (1) How do you feel in your class? $(1=$ very bad to $5=$ very good $)$, (2) How much do you feel accepted by your classmates? $(1=$ not at all to 5 = very much), (3) How many classmates do you think will nominate you as the one they like to socialize with most?, (4) How many classmates do you think will nominate you as the one they like to socialize with least?

\section{Academic self-efficacy}

The Academic Self-Efficacy scale of the Pattern of Adaptive Learning Scales (PALS, Midgley et al., 2000) measures students' perceptions of their capability to do class work (e.g., "I can do even the hardest work in this class if I try"). The five items are responded on a 5 -point scale $(1=$ not at all true; $5=$ very true). The authors of the original scale (Midgley et al., 2000) reported on its good internal reliability $(\alpha=0.78)$ which was also established using the current data $(\alpha=0.77)$.

\section{Academic performance}

Students were asked to report about their grade point average in the previous academic year $(1=$ unsatisfactory, $2=$ satisfactory, $3=$ good, $4=$ very good, $5=$ excellent $)$. The average academic performance for the whole sample was $3.32(\mathrm{SD}=0.94)$.

Parental consent was sought and granted for students to participate in the study. The administration of questionnaires took place in classes. Each session lasted 45 minutes. Students were told that the aim of the study was to learn more about their social relationships, and their feelings and thoughts about certain social and academic situations. We could not guarantee for students' full anonymity because they had to write down their names in peer nomination measures. Nevertheless, we ensured the students that their results would be used exclusively for the purposes of the study. Standard instructions were then read aloud. The students first filled in the SASA and Academic Self-Efficacy, in that order. Then we sought for peer nominations by applying the Sociometric Test and the Guess Who technique. Next, students answered additional questions about their self-perceptions in the classroom and reported about their grade point average in the previous academic year. 


\section{RESULTS}

\section{Social anxiety and social acceptance}

First, we identified social acceptance of each student by classifying them into five sociometric groups. The percentages of students across the sociometric groups were as follows: popular $26.4 \%$, rejected $16.6 \%$, neglected $14.8 \%$, controversial $6.1 \%$, and average $36.1 \%$. A relatively small number of students who belong to the controversial sociometric group (in our case 17) was also reported by other authors (e.g., Bukowski \& Newcomb, 1985; Coie \& Dodge, 1988; Terry \& Coie, 1991) and probably reflects the fact that controversial students possess ex-

(1) TABLE 2

Social anxiety of students classified into five sociometric groups; means, (SDs), and results of univariate ANOVAs tremely mixed behavioural tendencies (Dodge, 1983) which cause a highly variable perception of them by peers.

The results on relationship between students' sociometric classification and their score on the two subscales and total scale of the SASA are presented in Table 2.

\begin{tabular}{lccccccc}
\hline & \multicolumn{5}{c}{ Sociometric group } \\
\cline { 2 - 8 } & $\begin{array}{c}\text { Popular } \\
(\mathrm{n}=73)\end{array}$ & $\begin{array}{c}\text { Rejected } \\
(\mathrm{n}=46)\end{array}$ & $\begin{array}{c}\text { Neglected } \\
(\mathrm{n}=41)\end{array}$ & $\begin{array}{c}\text { Controversial } \\
(\mathrm{n}=17)\end{array}$ & $\begin{array}{c}\text { Average } \\
(\mathrm{n}=100)\end{array}$ & $\mathrm{F}$ & $\eta^{2}$ \\
\hline AFNE & 38.68 & 42.59 & 38.07 & 39.85 & 37.87 & 1.69 & 0.02 \\
& $(11.08)$ & $(11.31)$ & $(11.27)$ & $(12.85)$ & $(9.45)$ & & \\
TISC & $31.24 \mathrm{~b}$ & $36.41^{\mathrm{a}}$ & $30.67 \mathrm{~b}$ & 33.06 & $31.61^{\mathrm{b}}$ & $4.75^{* *}$ & 0.06 \\
& $(6.98)$ & $(8.88)$ & $(5.65)$ & $(7.83)$ & $(7.37)$ & \\
SASA-Total & 69.92 & $79.00^{\mathrm{a}}$ & 68.74 & 72.91 & $69.48^{\mathrm{b}}$ & $3.46^{* *}$ & 0.05 \\
& $(15.98)$ & $(18.42)$ & $(14.55)$ & $(17.98)$ & $(14.79)$ & & \\
\hline
\end{tabular}

Note. ${ }^{* *} \mathrm{p}<0.01$. Means with different superscript differ at $\mathrm{p}<0.05 . \eta^{2}=$ partial eta squared. AFNE $=$ Apprehension and Fear of Negative Evaluation, TISC $=$ Tension and Inhibition in Social Contact, SASA = Social Anxiety Scale for Adolescents.

Levene's Test of Homogeneity of Variance confirmed that the five sociometric groups have approximately equal variance on the social anxiety variables $(\mathrm{p}=0.24,0.15$, and 0.17 for the AFNE, TISC and SASA-Total, respectively). A basic assumption of ANOVA was thus verified. Results of ANOVA showed that five sociometric groups differ significantly in their TISC and SASA-Total score. Post-hoc Schéffe test showed that rejected students reported more tension and inhibition in social contacts than their popular $(\mathrm{p}<0.01)$, neglected $(\mathrm{p}<0.05)$ and average $(\mathrm{p}<0.05)$ peers. Only one significant difference appeared among sociometric groups in their total social anxiety score: rejected students had significantly higher score on the SASA-Total than their average peers $(p<0.05)$. The five sociometric groups did not differ in apprehension and fear of negative evaluation (AFNE).

In the next step, we analyzed the relationship between social anxiety and students' personal and behavioural characteristics as perceived by their classmates (Table 3). 


\begin{tabular}{lcccccccccc}
\hline & VA & NM & PA & HI & AN & PB & AAO & RT & OB & PM \\
\hline AFNE & -0.02 & $0.26^{* *}$ & -0.06 & $-0.13^{*}$ & $0.27^{* *}$ & 0.04 & 0.08 & 0.05 & $-0.16^{* *}$ & $-0.14^{*}$ \\
TISC & -0.11 & $0.27^{* *}$ & -0.09 & $-0.19^{* *}$ & $0.39^{* *}$ & -0.05 & 0.05 & 0.10 & $-0.17^{* *}$ & $-0.21^{* *}$ \\
SASA-Total & -0.06 & $0.30^{* *}$ & -0.08 & $-0.17^{* *}$ & $0.36^{* *}$ & 0.00 & 0.07 & 0.08 & $-0.18^{* *}$ & $-0.19^{* *}$
\end{tabular}

** $\mathrm{p}<0.01 ;{ }^{*} \mathrm{p}<0.05$

Note. $\mathrm{N}=277$. VA = Verbal Aggressiveness, $\mathrm{NM}=$ Negative Mood, $\mathrm{PA}=$ Physical Aggressiveness, $\mathrm{HI}=$ Hyperactivity, $\mathrm{AN}=$ Anxiety, $\mathrm{PB}=$ Prosocial Behaviour, $\mathrm{AAO}=$ Academic Achievement Orientation, $\mathrm{RT}=$ Relationships with Teachers, $\mathrm{OB}=$ Oppositional Behaviour, $\mathrm{PM}=$ Positive Mood, AFNE = Apprehension and Fear of Negative Evaluation, TISC = Tension and Inhibition in Social Contact, SASA = Social Anxiety Scale for Adolescents.

(1) TABLE 3

Correlations between social anxiety and number of peer nominations in personal and behavioural domains

(1) TABLE 4

Correlations between social anxiety and self-perceptions of social status in classroom
The results showed the highest relationships between social anxiety and peer nominations of students' anxiety and negative mood. Students who scored higher on AFNE, TISC and SASA-Total were perceived by their classmates as more anxious (shy, worried) and showing more negative mood (negative feelings) than students with lower social anxiety scores. Accordingly, socially more anxious students received less peer nominations in the category "positive mood" than their socially less anxious peers. On the other hand, classmates perceived less oppositional behaviour (i.e., breaking the rules, talking back to teachers) and less hyperactivity (being loud and disturbing others at work) in socially more than less anxious students. According to Cohen (1988), these correlations had a small $(\geq 0.10$ and $<0.30)$ to average $(\geq 0.30$ and $<0.50)$ magnitude.

As already described, students also reported about their feelings and self-perceived social acceptance in the classroom. The results on the relationship between social anxiety and self-perceptions in the classroom (Table 4) showed that all correlations are significant. Students who reported higher fear of negative social evaluation (AFNE), higher tension and inhibition in social contacts (TISC) and higher social anxiety total score also had more negative feelings in the classroom, more negative perceptions of peer acceptance, less anticipations of positive peer nominations and more anticipations of negative peer nominations. These correlations are again of a small to average magnitude.

Positive feelings Perceptions of Number of anticipated Number of anticipated in classroom peer acceptance positive nominations negative nominations

\begin{tabular}{lllll}
\hline AFNE & $-0.22^{* *}$ & $-0.30^{* *}$ & $-0.14^{*}$ & $0.23^{* *}$ \\
TISC & $-0.29^{* *}$ & $-0.38^{* *}$ & $-0.17^{* *}$ & $0.29^{* *}$ \\
SASA-Total & $-0.28^{* *}$ & $-0.37^{* *}$ & $-0.17^{* *}$ & $0.29^{* *}$ \\
\hline
\end{tabular}

Note. $\mathrm{N}=277 .{ }^{* *} \mathrm{p}<0.01 ;{ }^{*} \mathrm{p}<0.05$. 


\section{Social anxiety and academic performance}

In the last part of the analyses, we answered the question on how social anxiety in students relates to their academic self-efficacy and academic performance. The results showed that students who scored higher on the TISC and SASA-Total perceived lower academic self-efficacy. On the other hand, socially more anxious students had higher academic performance (grade point average) than their socially less anxious peers. The magnitude of all correlations is small.

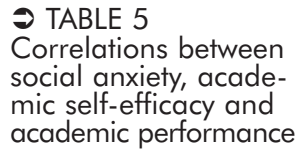

\begin{tabular}{lcc}
\hline & Academic self-efficacy & Academic performance \\
\hline AFNE & -0.11 & $0.13^{*}$ \\
TISC & $-0.17^{* *}$ & $0.18^{* *}$ \\
SASA-Total & $-0.15^{*}$ & $0.17^{* *}$ \\
\hline
\end{tabular}

Note. $\mathrm{N}=277 .{ }^{*} \mathrm{p}<0.01 ;{ }^{*} \mathrm{p}<0.05$.

\section{DISCUSSION}

The present study extends the literature by examining the relationship between high school students' social anxiety and their social acceptance in the classroom. The data on students' social acceptance were collected from two informant sources: (a) peer perceptions of one's social acceptance in the classroom and his/her personal and behavioural characteristics, and (b) self-perceptions of social acceptance and well-being in the classroom. The second research aim was to examine the relationship between students' social anxiety and academic self-efficacy and performance.

The results revealed that students who belonged to the least favourable sociometric group (i.e. rejected students) reported the highest level of social anxiety. More specifically, rejected students had more tension and inhibition in social contacts than their classmates classified as popular, neglected and average. Similarly, they report the highest overall social anxiety score. The result thus supports previous studies which found similar relationship in adolescent groups (Inderbitzen et al., 1997; La Greca \& Lopez, 1998). However, students in the five sociometric groups did not differ in their self-reports on apprehension and fear of negative evaluation. The first hypothesis has thus been only supported for the expected positive relationship between feelings of fear and avoidance in contingent (direct) social interactions and difficulties with social acceptance in the classroom, while the cognitive aspect of social anxiety (worries about negative social evaluation) does not seem to be related to peer rejection. 
DRUŠ. ISTRAŽ. ZAGREB GOD. 21 (2012), BR. 2 (116)

STR. $405-419$

PUKLEK LEVPUŠČEK, M., BERCE, J:

SOCIAL ANXIETY...
According to our second hypothesis, students with higher levels of social anxiety were more frequently nominated by their peers as being anxious and showing a more negative and less positive mood. However, socially more anxious students were also perceived by their classmates as being less oppositional and hyperactive in the classroom than their less socially anxious mates. Peer reports thus showed that socially anxious students display behaviours which place them at risk for lower peer acceptance and internalised symptoms. Such behaviours might be, for example, frequent signs of bad mood and sadness, and constant worries and fears in social contacts. In accordance with this result, Puklek Levpušček (2008) found that adolescents with higher social anxiety also scored higher on neuroticism (being fearful and insecure, showing negative emotionality and shyness). On the other hand, our results showed that peers do not perceive socially anxious classmates as oppositional or hyperactive, which again indicates the internalised but not externalised nature of the social anxiety syndrome.

We confirmed the third hypothesis about the relationship between social anxiety and self-perceptions of social acceptance and well-being in the classroom. Students with higher levels of social anxiety perceived their social status in the classroom to be less favourable than their less socially anxious mates. The former group felt less accepted by their classmates, had more negative feelings in the classroom and anticipated less positive and more negative peer nominations than the latter group. The results confirmed previous findings about the negative relationship of social anxiety with self-perceived social competence (e.g., La Greca and Lopez, 1998; Puklek \& Vidmar, 2000). Socially anxious students are aware of their less favourable social status in the classroom, lower peer acceptance and rejection. Perceived social rejection is likely to enhance their feelings of incompetence in social situations, decrease their self-esteem and raise fears of negative peer evaluation (Festa \& Ginsburg, 2011). Consequently, socially anxious students do not participate actively in social interactions but rather take a passive stand. Peers do not choose them as social partners whom they like to play or socialize with. In consequence, feelings of anxiety further increase due to one's failure in establishing and maintaining close relationships, which creates a vicious circle. Nonetheless, we should also consider the fact that socially anxious students may overestimate the probability of negative social events (Rheingold et al., 2003) and thus expect less positive and more negative nominations from their peers.

The fourth hypothesis was only partially supported. Students with higher levels of tension and inhibition in social contact (TISC) and higher overall social anxiety score (SASA-Total) 
DRUŠ. ISTRAŽ. ZAGREB GOD. 21 (2012),

BR. 2 (116)

STR. $405-419$

PUKLEK LEVPUŠČEK, M., BERCE, J.:

SOCIAL ANXIETY..

\section{REFERENCES}

reported about lower levels of academic self-efficacy. However, the magnitude of correlations was small and the cognitive aspect of social anxiety (AFNE) did not relate to academic self-efficacy.

As has already been indicated by some previous studies (La Greca \& Lopez, 1998; Puklek Levpušček \& Videc, 2008), socially anxious students do not necessarily show lower academic outcomes than their socially less anxious mates. According to the results of our study, the truth might even be quite the opposite: they get better school grades. The positive correlation between social anxiety and academic success was, however, of a small magnitude and thus precludes a strong practical significance of this result.

There are several limitations to the current study. The sociometric groups were rather imbalanced in terms of the number of students who belonged to particular groups (e.g., only 17 students had a controversial sociometric status). The small number of students, in particular sociometric groups, probably affected the statistical power of analyses. Furthermore, the sample consisted of high school students from gymnasiums and was thus fairly homogeneous. This fact limits the generalizability of our results. Next, since the current study relied on cross-sectional data, no conclusions can be drawn about the causal relations between social anxiety and social acceptance. Future research should answer the question about the causal or bidirectional nature of the relationship. In addition, future research should also examine a wider range of academic self-perceptions and behaviours (e.g., aspirations, achievement goals, self-handicapping strategies, use of learning strategies) in socially anxious students. This might better explain how socially anxious students cope with achievement settings and what strategies they use to overcome difficulties with anxious symptoms.

Asher, S. R. and Wheeler, V. A. (1985), Children's Loneliness: A Comparison of Rejected and Neglected Peer Status. Journal of Consulting and Clinical Psychology, 53 (4): 500-505. doi:10.1037//0022-006X.53.4.500

Berce, J. (2010), Povezanost med socialno anksioznostjo, položajem v razredu in učnim vedenjem srednješolcev [Relationship among Social Anxiety, Social Status and Learning Behaviors of High School Students], University of Ljubljana, Department of Psychology, Unpublished bachelor's thesis.

Bukowski, W. M. and Newcomb, A. F. (1985), Variability in Peer Group Perceptions: Support for the "Controversial" Sociometric Classification Group. Developmental Psychology, 21 (6): 1032-1038. doi:10.1037// 0012-1649.21.6.1032

Cheek, J. M. and Melchior, L. A. (1990), Shyness, Self-Esteem, and Self-Consciousness. In: H. Leitenberg (Ed.), Handbook of Social and Evaluation Anxiety (pp. 47-82), New York, Plenum Press. 
DRUŠ. ISTRAŽ. ZAGREB GOD. 21 (2012), BR. 2 (116) STR. $405-419$

PUKLEK LEVPUŠČEK, M., BERCE, J.: SOCIAL ANXIETY...
Clark, D. and Wells, A. (1995), A Cognitive Model of Social Phobia. In: R. G. Heimberg and M. R. Liebowitz (Eds.), Social Phobia: Diagnosis, Assessment, and Treatment (pp. 69-93), New York, Guilford.

Cohen, J. (1988), Statistical Power Analysis for the Behavioral Sciences, Hillsdale, NY, Erlbaum.

Coie, J. D. and Dodge, K. A. (1988), Multiple Sources of Data on Social Behavior and Social Status in the School: A Cross-Age Comparison. Child Development, 59 (3): 815-829. doi:10.2307/1130578

Coie, J. D., Dodge, K. A. and Coppotelli, H. (1982), Dimensions and Types of Status: A Cross-Age Perspective. Developmental Psychology, 18 (4): 557-570. doi:10.1037//0012-1649.18.4.557

Crick, N. R. and Ladd, G. W. (1993), Children's Perceptions of their Peer Experiences: Attributions, Loneliness, Social Anxiety and Social Avoidance. Developmental Psychology, 29 (2): 244-254. doi:10.1037//00121649.29.2.244

Delgado Domenech, B. (2010), Personality Variables, Cognitive-Emotional Variables, and Social Variables Related to Academic Performance of Students with Social Anxiety in Compulsory Secondary Education, Unpublished doctoral thesis, Miguel Hernandez University of Elche.

Dodge, K. A. (1983), Behavioral Antecedents of Peer Social Status. Child Development, 54 (6): 1386-1399. doi:10.2307/1129802

Festa, C. C. and Ginsburg, G. S. (2011), Parental and Peer Predictors of Social Anxiety in Youth. Child Psychiatry and Human Development, 42 (3): 291-306. doi:10.1007/s10578-011-0215-8

Garcia-Lopez, L. J., Inglés, C. J., Puklek Levpušček, M., García-Fernández, J. M., Hidalgo, M. D. and Bermejo, R. (2011), Psychometric Properties and Clinical Cut-Off Scores of the Spanish Version of the Social Anxiety Scale for Adolescents. Journal of Personality Assessment, 93 (5): 474-482. doi:10.1080/00223891.2011.594126

Glickman, A. R. and La Greca, A. M. (2004), The Dating Anxiety Scale for Adolescents: Scale Development and Associations with Adolescent Functioning. Journal of Clinical Child and Adolescent Psychology, 33 (3): 566-578. doi:10.1207/s15374424jccp3303_14

Hartshorne, H. and May, M. A. (1928), Studies in Deceit, New York, Macmillan.

Hecht, D. B., Inderbitzen, H. M. and Bukowski, A. L. (1998), The Relationship between Peer Status and Depressive Symptoms in Children and Adolescents. Journal of Abnormal Child Psychology, 26 (2): 153-160. doi:10.1023/A:1022626023239

Hymel, S. and Franke, S. (1985), Children's Peer Relations: Assessing Self-Perceptions. In: B. H. Schneider, K. H. Rubin and J. E. Ledingham (Eds.), Children's Peer Relations: Issues and Assessment and Intervention (pp. 75-92), New York, Springer-Verlag.

Inderbitzen, H. M., Walters, K. S. and Bukowski, A. L. (1997), The Role of Social Anxiety in Adolescent Peer Relations: Differences among Sociometric Status Groups and Rejected Subgroups. Journal of Clinical Child Psychology, 26 (4): 338-348. doi:10.1207/s15374424jccp2604_2

La Greca, A. M. (1989), Social Anxiety Scale for Children: Scale Development and Validation. Paper Presented at the Meeting of the Society for Research in Child and Adolescent Psychopathology, Miami. 
DRUŠ. ISTRAŽ. ZAGREB GOD. 21 (2012),

BR. 2 (116),

STR. $405-419$

PUKLEK LEVPUŠČEK, $M$. BERCE, J.: SOCIAL ANXIETY..
La Greca, A. M., Dandes, S. K., Wick, P., Shaw, K. and Stone, W. L. (1988), Development of the Social Anxiety Scale for Children. Reliability and Concurrent Validity. Journal of Clinical Child Psychology, 17 (1): 84-91. doi:10.1207/s15374424jccp1701_11

La Greca, A. M. and Lopez, N. (1998), Social Anxiety among Adolescents: Linkages with Peer Relations and Friendships. Journal of Abnormal Child Psychology, 26 (2): 83-94. doi:10.1023/A:1022684520514

La Greca, A. M. and Moore Harisson, H. (2005), Adolescent Peer Relations, Friendships, and Romantic Relationships: Do They Predict Social Anxiety and Depression? Journal of Clinical Child and Adolescent Psychology, 34 (1): 49-61. doi:10.1207/s15374424jccp3401_5

La Greca, A. M. and Stone, W. L. (1993), Social Anxiety Scale for Children-Revised: Factor Structure and Concurrent Validity. Journal of Clinical Child Psychology, 22 (1): 17-27. doi:10.1207/s15374424jccp2201_2

Leitenberg, H. (1990), Introduction. In: H. Leitenberg (Ed.), Handbook of Social and Evaluation Anxiety (pp. 1-8), New York, Plenum Press.

Midgley, C., Maehr, M. L., Hruda, L. Z., Anderman, E. M., Hicks Anderman, L., Freeman, K. E. et al. (2000), Manual for the Patterns of Adaptive Learning Scale, The University of Michigan.

Moreno, J. L. (1953), Who Shall Survive? A New Approach to the Problem of Human Interrelations, Washington, DC, Nervous and Mental Disease Publishing Co. (original work published 1934).

Pečjak, S. and Košir, K. (2002), Poglavja iz pedagoške psihologije. Izbrane teme, Ljubljana, Oddelek za psihologijo Filozofske fakultete.

Puklek, M. (1997), Modeli socialne anksioznosti. Horizons of Psycho$\log y, 6$ (3): 63-75.

Puklek Levpušček, M. (2004), Development of the Two Forms of Social Anxiety in Adolescence. Horizons of Psychology, 13 (3): 27-40.

Puklek Levpušček, M. (2006), Socialna anksioznost v otroštvu in mladostništvu: razvojni, šolski in klinični vidik [Social Anxiety in Childhood and Adolescence: Developmental, Educational and Clinical Perspective], Ljubljana, Znanstveno raziskovalni inštitut Filozofske fakultete.

Puklek Levpušček, M. (2008), Lestvica socialne anksioznosti za mladostnike (LSAA): priročnik [Social Anxiety Scale for Adolescents (SASA): Manual], Ljubljana, Psychological Test Publishing, Assessment and Consultancy.

Puklek Levpušček, M. and Videc, M. (2008), Psychometric Properties of the Social Anxiety Scale for Adolescents (SASA) and its Relation to Positive Imaginary Audience and Academic Performance in Slovene Adolescents. Studia Psychologica, 50 (1): 49-65.

Puklek, M. and Vidmar, G. (2000), Social Anxiety in Slovene Adolescents: Psychometric Properties of a New Measure, Age Differences and Relations with Self-Consciousness and Perceived-Incompetence. European Review of Applied Psychology, 50 (2): 249-258.

Rheingold, A. A., Herbert, J. D. and Franklin, M. E. (2003), Cognitive Bias in Adolescents with Social Anxiety Disorder. Cognitive Therapy and Research, 27 (6): 639-655. doi:10.1023/A:1026399627766;

Schenkler, B. R. and Leary, M. R. (1982), Social Anxiety and Self Presentation: A Conceptualization and Model. Psychological Bulletin, 92 (3): 641-669. 
DRUŠ. ISTRAŽ. ZAGREB GOD. 21 (2012), BR. 2 (116)

STR. $405-419$

PUKLEK LEVPUŠČEK, M., BERCE, J:

SOCIAL ANXIETY...
Strauss, C. C., Frame, C. L. and Forehand, R. (1987), Psychosocial Impairment Associated with Anxiety in Children. Journal of Clinical Child Psychology, 16 (3): 235-239. doi:10.1207/s15374424jccp1603_8

Terry, R. and Coie, J. D. (1991), A Comparison of Methods for Defining Sociometric Status among Children. Developmental Psychology, 27 (5): 867-880. doi:10.1037//0012-1649.27.5.867

Vernberg, E. M. (1990), Psychological Adjustment and Experiences with Peers during Early Adolescence: Reciprocal, Incidental, or Unidirectional Relationships? Journal of Abnormal Child Psychology, 18 (2): 187-198. doi:10.1007/BF00910730

Vernberg, E. M., Abwender, D. A., Ewell, K. K. and Beery, S. H. (1992), Social Anxiety and Peer Relationships in Early Adolescence: A Prospective Analysis. Journal of Clinical Child Psychology, 21 (2): 189-196. doi:10.1207/s15374424jccp2102_11

Westenberg, P. M., Drewes, M. J., Goedhart, A. W., Siebelink, B. M. and Treffers, P. D. A. (2004), A Developmental Analysis of Self-Reported Fears in Late Childhood through Midadolescence: Social-Evaluative Fears on the Rise? Journal of Child Psychology and Psychiatry, 45 (3): 481-495.

\section{Socijalna anksioznost, socijalna prihvaćenost i akademsko samoopažanje učenika gimnazija}

\author{
Melita PUKLEK LEVPUŠČEK \\ Filozofski fakultet, Ljubljana \\ Jelka BERCE \\ Srednja škola za farmaciju, kozmetiku \\ i zdravstvo, Ljubliana
}

Studiija se bavi istraživanjem međuodnosa socijalne anksioznosti i prihvaćenosti među vršnjacima, akademskom samoučinkovitosti i akademskom uspješnosti učenika slovenskih gimnazija. $N=277$ učenika (58\% djevojaka) od 16 do 17 godina, ispunilo je Ljestvicu socijalne anksioznosti za adolescente, Sociometrijjki test, upitnik "Pogodi tko" te Ljestvicu akademske samoučinkovitosti. Učenici su odgovorili i na dodatna pitanja o njihovoi dobrobiti i socijalnoi prihvaćenosti u razredu. Nalazi su pokazali da većina socijalno anksioznih učenika pripada sociometrijskoi skupini odbačenih učenika, koje su njihovi vršnjaci opisali kao anksiozne učenike negativna raspoloženja. Pokazalo se da socijalno anksiozniji učenici imaju niži stupanj dobrobiti u razredu i da ih njihovi vršnjaci manje prihvaćaju. Konačno, viši stupanj socijalne anksioznosti bio je povezan s nižom akademskom samoučinkovitosti, ali s boljim akademskim uspjehom u školi.

Ključne riječi: socijalna anksioznost, socijalna prihvaćenost, akademska samoučinkovitost, učenici gimnazija 